\title{
COMBINED OPERATION OF AC AND DC DISTRIBUTION SYSTEM WITH DISTRIBUTED GENERATION UNITS
}

\author{
Reza Noroozian * - Mehrdad Abedi ${ }^{* *}$ — Gevorg Gharehpetian ${ }^{* *}$
}

\begin{abstract}
This paper presents a DC distribution system which has been supplied by external AC systems as well as local DG units in order to demonstrate an overall solution to power quality issue. In this paper, the proposed operation method is demonstrated by simulation of power transfer between external AC systems, DG units, AC and DC loads. The power flow control in DC distribution system has been achieved by network converters and DG converters. Also, the mathematical model of the network, DG and load converters are obtained by using the average technique, which allows converter systems accurately simulated and control strategies for this converters is achieved. A suitable control strategy for network converters has been proposed that involves DC voltage droop regulator and novel instantaneous power regulation scheme. Also, a novel control technique has been proposed for DG converters. In this paper, a novel control system based on stationary and synchronously rotating reference frame has been proposed for load converters for supplying AC loads connected to the DC bus by balanced voltages. The several case studies have been studied based on proposed methods. The simulation results show that DC distribution systems including DG units can improve the power quality at the point of common coupling (PCC) in the power distribution system or industrial power system.
\end{abstract}

Keywords: power quality, DC distribution system, distributed generation, microturbine unit, fuel cell unit

\section{INTRODUCTION}

Custom power devices have widely studied by many researchers as an ultimate method to improve power quality $[1,2]$. The function of custom power devices is to mitigate the disturbances that affect the performance of the critical loads. Series custom power device injects an active power $(P)$ and reactive power $(Q)$ into the distribution system to achieve voltage compensation $[3,4]$. Also, parallel custom power device injects $P$ and $Q$ to achieve current compensation $[5,6]$. Combined series and parallel custom power devices inject $P$ and $Q$ to achieve both voltage and current compensations $[7,8]$. Most of these devices can not compensate the voltage interruptions because they have no energy storage in their DC link. These devices have been used to solve specific power quality problems such as voltage sags, swells, outages, flickers, and harmonics. However, co-ordination of these custom power devices for power quality and reliability enhancement is quite a hard task. The interest in DG has been rapidly increasing because DG is considered to play an important role in the future power system $[9,10]$. Several studies have proposed the interconnection of DG units with power systems using voltage-source-converters (VSCs) as versatility of VSCs helps in improving the ability of DG [11-13],[25, 26]. Moreover, the power electronic interface for DG units has the ability to control the voltage and current disturbances. As a result, the integration of DG units in AC and DC distribution systems provide additional performance which is superior to the combination of the UPS system and custom power devices. It is shown that DC distribution systems offer high power density, high efficiency and tightly regulated output voltage as needed by telecommunication equipments, shipboard systems and traction systems [14-17]. This paper proposes a combined AC and DC distribution system including DG units. The advantage of the proposed system over the custom power devices is that it can compensate voltage interruptions, as well as voltage sags, voltage swells, harmonics, and the reactive power. The simulation results show that the proposed system can improve the power quality at the point of installation in the distribution system or industrial power system.

\section{DC DISTRIBUTION SYSTEM CONFIGURATION}

Figure 1 shows the DC distribution system considered for study in this paper. The proposed system is equipped with generating sources in the form of DGs, instead of UPSs. The DC bus is assumed to be lossless and is connected to the AC distribution system by two AC-to-DC network converters in order to enhance the system reliability. These converters are assumed to have equal power ratings [1]. Considering the merits of VSCs [1], [18], they are employed as interface between AC grid and DC bus. The power fed to the DC bus is supplied by two external AC feeders. These feeders are assumed to be connected to independent substations. In this system, it is assumed that two fuel cell units, with equal power ratings, are connected to the DC bus via DC-to-DC converters while two microturbine units, with equal power

\footnotetext{
* Department of Electrical Engineering, Faculty of Engineering, University of Zanjan, PO Box 45195-313, Zanjan, Iran, noroozian@znu.ac.ir ** Department of Electrical Engineering, Amirkabir University of Technology, Iran, abedi@aut.ac.ir, grptian@aut.ac.ir
} 


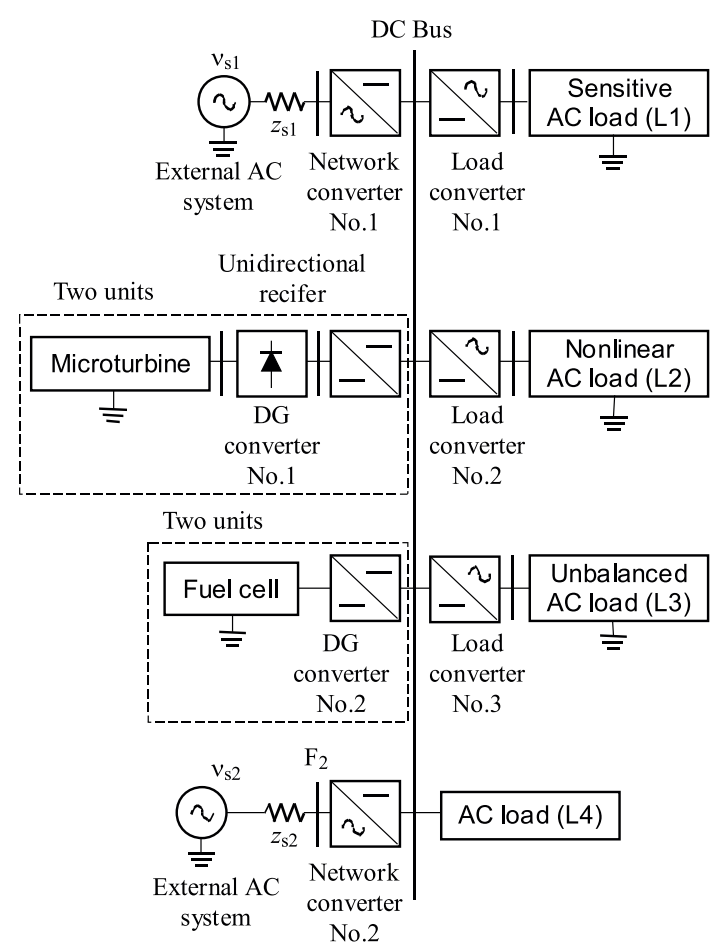

Fig. 1. DC distribution system with distributed generation units
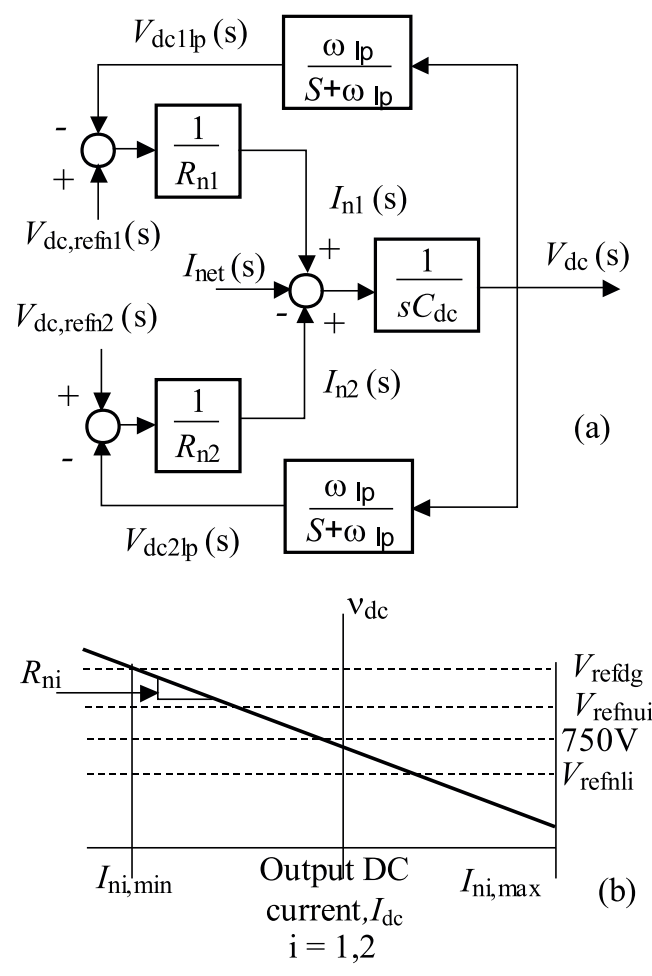

Fig. 3. (a) Structure of the DC bus voltage droop controller; (b) Droop characteristics of network converters

ratings, are connected to the DC bus through diode rectifier and DC-to-DC converter. The DC-to-DC converters are called as DG converters. The chosen number of each DG units is arbitrary. The loads fed by DC bus, in Fig. 1, can be divided into four categories

a) L1 is a sensitive or critical load, which requires uninterrupted sinusoidal voltage.

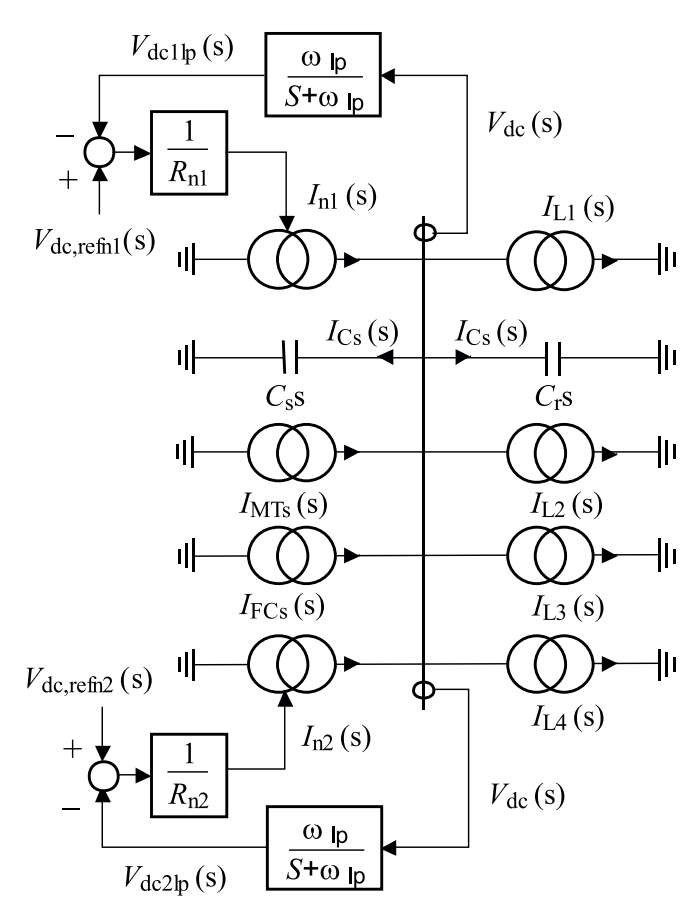

Fig. 2. DC side dynamic model

b) L2 is a nonlinear load, which draws harmonic currents.

c) L3 is an unbalanced AC load which draws unbalanced currents.

d) L4 is a DC load directly connected to the DC bus.

Power balancing in DC bus could be achieved by AC-to-DC network converters equipped with DC voltage regulator, which adjust the DC voltage at acceptable limit during steady state and dynamic conditions. Therefore, the active power of DG units can be injected to the DC bus and all the loads connected to the DC bus can be supplied with the constant DC voltage. The power regulation of DGs can be specified by various criteria such as maximum efficiency conditions or thermal load requirements [19]. Thus, considering both technical and economical constraints, the control system of DGs converters should not be designed to support the power balancing for DC bus. In the system, shown in Fig. 1, the energy storage system is not required to support the $\mathrm{DC}$ voltage. The objective of this system selection is to demonstrate the overall solution to power quality, reliability, energy-delivery efficiency problems due to lack of energy storage system and the possibility of the DC bus utilization in parallel with external AC network or in islanding mode during AC grid outages.

\section{POWER MANAGEMENT STRATEGY}

The objective of the power management strategy is to achieve optimal operational performance providing high power quality, reliability and efficient energy dispatch. Power management strategy of network converters should 
provide the reference active and reactive power signals for the power regulation. The reference active power signal of a network converter is determined by the DC voltage regulator system, which will be discussed in the next section. The reference reactive power of a network converter in $\mathrm{AC}$ side is specified by its reactive power management strategy which is usually Unity Power Factor (UPF) operation mode $[20,21]$. The reference active power of a DG unit is specified by its power management system. The generators supplied by non-renewable sources, such as microturbines and fuel cells, the active power management strategies consider various criteria, such as maximum efficiency conditions or thermal load requirements [19]. In synchronous generators connected to microturbine, power factor control, eg UPF, is usually adopted to maximize the active power generation [20-22]. For the system, shown in Fig. 1, the following assumptions have been made:

a) The proposed control strategy is based on locally measured signals since no communication exists among DG units and network converters.

b) The control scheme of the network converter is based on the control loop feedback of the DC voltage because this is the only common signal for power balancing in DC bus. Moreover, each network converter is equipped with DC voltage regulator with relatively slow response for real power control.

c) Each network converter should inject the power from the external AC network to the DC bus if the available DC power generation is not sufficient for supplying the system loads.

d) None of the DG units acts as a spinning reserve or as a back-up generator.

e) DG units are expected to supply pre-specified power, e.g. to minimize power import from the grid (peak shaving strategy).

f) Simple, fast and flexible real/reactive power control strategies are required to damp the proposed system oscillations, eg, due to islanding. (This cant be the assumption)

The dynamic model for the DC side of the system is shown in Fig. 2. Two network converters, connected in parallel, can be modeled by current sources controlled by DC bus voltage signal. These converters distribute the current changes between themselves. In addition, the power reference for two bidirectional network converters is provided by DC voltage regulator. The DG unit converters and load converters are operating in the current control mode. The control philosophy for two network converters is based on feedback from the DC bus voltage, $V_{d c}$ and the reference value for the DC bus voltage. If the DC bus voltage is low, the power should be injected to the DC bus by DG units or the external AC systems. If the DC bus voltage is high, the surplus power in DC bus must be returned to external AC systems. As it can be seen in Fig. 2, we have

$$
\begin{gathered}
I_{n 1}(s)+I_{n 2}(s)-\left(C_{s}+C_{r}\right) s V_{d c}(s)=I_{n 1}(s)+I_{n 2}(s)+ \\
I_{L 3}(s)+I_{L 4}(s)-I_{M T s}(s)-I_{F C s}(s)=I_{n e t}(s)
\end{gathered}
$$

$$
L_{n i}(s)=\frac{V_{d c, r e f n i}(s)-\frac{\omega_{l p}}{s+\omega_{l p}} V_{d c}(s)}{R_{n i}}, \quad i=1,2,
$$

where, $I_{n 1}$ and $I_{n 2}$ are the output currents of network converters No. 1 and No. 2 respectively. $I_{M T s}$ and $I_{F C s}$ are the output currents of microturbine and fuel cell units respectively. $I_{L 1}, I_{L 2}$ and $I_{L 3}$ are the output currents of load converters No. 1 , No. 2 and No. 3 respectively. $I_{L 4}$ is the current drawn by the load directly connected to the DC bus. $I_{\text {net }}$ is the current difference between the output current of all loads and DG units connected to the DC bus. $C_{S}$ is the equivalent capacitance of the network, storage and DG converters. Also $C_{r}$ is the equivalent capacitance of the load converters. $V_{d c, \text { refni }}$ and $I_{n i}$ are DC reference voltage and the output current of the $i$-th network converter respectively. $P_{n i}$ and $R_{n i}$ are the output DC power and the equivalent resistance of the $i$-th network converter respectively. The measured DC bus voltage is low pass filtered to attenuate the interaction between the negative sequence voltage of the $\mathrm{AC}$ side and DC bus voltage control and to enhance controller pole placement. $\omega_{l p}$ is the break-over frequency of the low pass filter (shown with LPF in Fig. 2). Considering equations (1), (2) and (3), the measured voltage, the reference voltages in DC bus $\left(V_{d c r e f n 1}\right.$ and $\left.V_{d c r e f n 2}\right)$ and the current difference between the output current of all loads and DG units $\left(I_{n e t}\right)$ can be presented in one block diagram as shown in Fig. 3(a). This figure shows the main structure of the DC bus voltage droop controller for the network converters. $C_{d c}$ which is equal to $C_{s}+C_{r}$, is the total equivalent capacitance of converters connected to the DC bus. From Fig. 3(a), we have

$$
\begin{aligned}
V_{d c}(s)= & \frac{\frac{1}{R_{n 1} C_{d c}}\left(s+\omega_{l p}\right)}{s^{2}+\omega_{l p} s+\frac{\left(R_{n 1}+R_{n 2}\right) \omega_{l p}}{R_{n 1} R_{n 2} C_{d c}}} V_{d c, r e f 1}(s) \\
& +\frac{\frac{1}{R_{n 2} C_{d c}}\left(s+\omega_{l p}\right)}{s^{2}+\omega_{l p} s+\frac{\left(R_{n 1}+R_{n 2}\right) \omega_{l p}}{R_{n 1} R_{n 2} C_{d c}}} V_{d c, r e f 2}(s) \\
& -\frac{\frac{1}{C_{d c}}\left(s+\omega_{l p}\right)}{s^{2}+\omega_{l p} s+\frac{\left(R_{n 1}+R_{n 2}\right) \omega_{l p}}{R_{n 1} R_{n 2} C_{d c}}} I_{n e t}(s) .
\end{aligned}
$$

The closed loop transfer function is given by the following equation

$$
P(s)=s^{2}+\omega_{l p} s+\frac{\left(R_{n 1}+R_{n 2}\right) \omega_{l p}}{R_{n 1} R_{n 2} C_{d c}} .
$$

The desired characteristic equation can be expressed as

$$
P(s)=s^{2}+2 \zeta_{n} \omega_{n} s+\omega_{n}^{2}
$$

where, $\zeta_{n}$ and $\omega_{n}$ are the desired closed loop damping and bandwidth, respectively. The value of DC bus equivalent capacitors determines the performance of the DC 


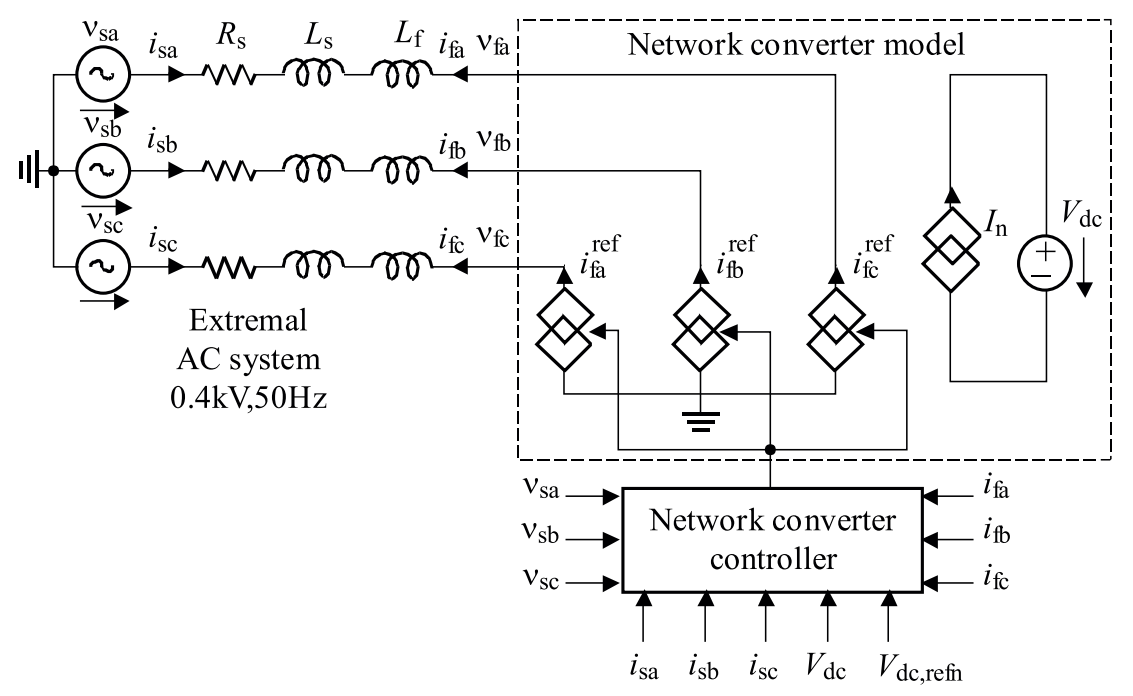

Fig. 4. Equivalent circuit of network converter

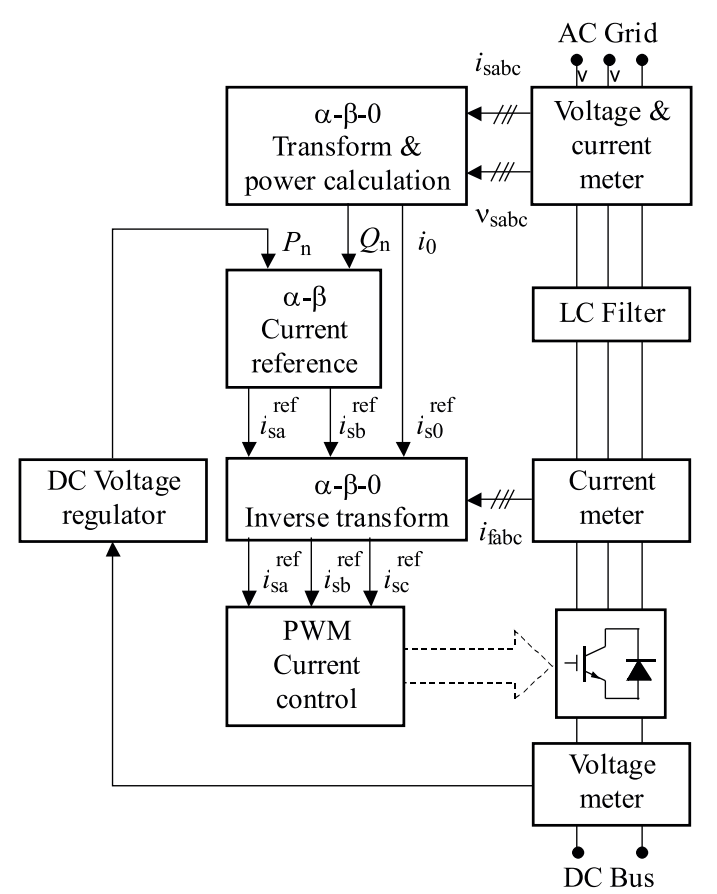

Fig. 5. Block diagram of network converter controller

voltage control system. The total required DC bus capacitor, $C_{d c}$, can be determined by using equations (4) and (5)

$$
\begin{aligned}
C_{d c} & =C_{s}+C_{r}=\frac{\left(R_{n 1}+R_{n 2}\right) 4 \zeta_{n}^{2}}{R_{n 1} R_{n 2} \omega_{l p}}, \\
\omega_{n} & =\frac{1}{2 \zeta_{n} \omega_{l p}} .
\end{aligned}
$$

The above mentioned equations can be written for the steady state condition as follows

$$
\begin{aligned}
L_{n 1}+L_{n 2} & =I_{n e t}, \\
I_{n i}(s) & =\frac{V_{d c, r e f n_{i}}-V_{d c}}{R_{n i}}, \quad i=1,2 .
\end{aligned}
$$

For $P_{n i}$ we have

$$
P_{n i}=V_{d c} I_{n i}=\frac{V_{d c}\left(V_{d c, r e f n i}-V_{d c}\right)}{R_{n i}}, \quad i=1,2 .
$$

Substituting equation (9) in the equation (8) we get

$$
V_{d c}=\frac{R_{n 2} V_{d c, r e f n 1}+R_{n 1} V_{d c, r e f n 2}-R_{n 1} R_{n 2} I_{n e t}}{R_{n 1}+R_{n 2}} .
$$

Using equations (9) and (11), we obtain

$$
\begin{aligned}
I_{n 1} & =\frac{R_{n 2} I_{n e t}}{R_{n 1}+R_{n 2}}+\frac{V_{d c, r e f n 1}-V_{d c, r e f n 2}}{R_{n 1}+R_{n 2}}, \\
I_{n 2} & =\frac{R_{n 1} I_{n e t}}{R_{n 1}+R_{n 2}}-\frac{V_{d c, r e f n 1}-V_{d c, r e f n 2}}{R_{n 1}+R_{n 2}} \\
I_{c} & =\frac{V_{d c, r e f n 1}-V_{d c, r e f n 2}}{R_{n 1}+R_{n 2}} .
\end{aligned}
$$

It is clear that if $V_{d c, r e f n 1}=V_{d c, r e f n 2}=V_{d c, r e f n}$, then the circulating current, $I_{c}$, is equal to zero. In addition, if $R_{n 1}=R_{n 2}=R_{n}$, then the injected currents to the DC bus via network converters, $I_{n 1}$ and $I_{n 2}$, are equal. However, the proper load sharing can be obtained by the appropriate selection of $R_{n i}$. The voltage droop, delta, can be defined as follows

$$
\delta=\frac{V_{d c, r e f n 1}-V_{d c}}{V_{d c, r e f n 1}}=\frac{V_{d c, r e f n 2}-V_{d c}}{V_{d c, r e f n 2}} .
$$

The equation (10) can be rewritten in the following form

$$
P_{n i}=\frac{\delta(1-\delta) V_{d c, r e f n i}^{2}}{R_{n i}}, \quad i=1,2 .
$$

At rated power conditions, equation (16) can be rewritten as follows

$$
\begin{aligned}
& P_{n i, \text { rated }}=\frac{\delta_{n}\left(1-\delta_{n}\right) V_{d c, \text { refni }}^{2}}{R_{n i}}, \quad i=1,2, \\
& R_{n i}=\frac{\delta_{n}\left(1-\delta_{n}\right) V_{d c, \text { refni }}^{2}}{P_{n i, \text { rated }}}, \quad i=1,2 .
\end{aligned}
$$




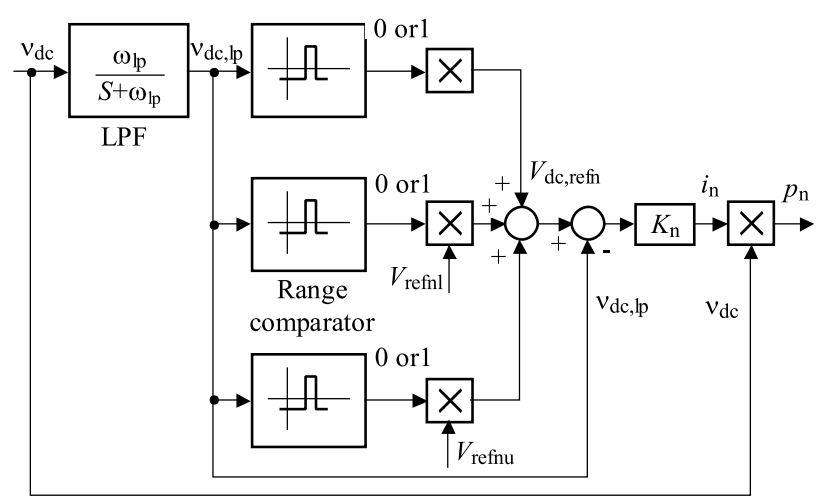

Fig. 6. DC voltage regulator
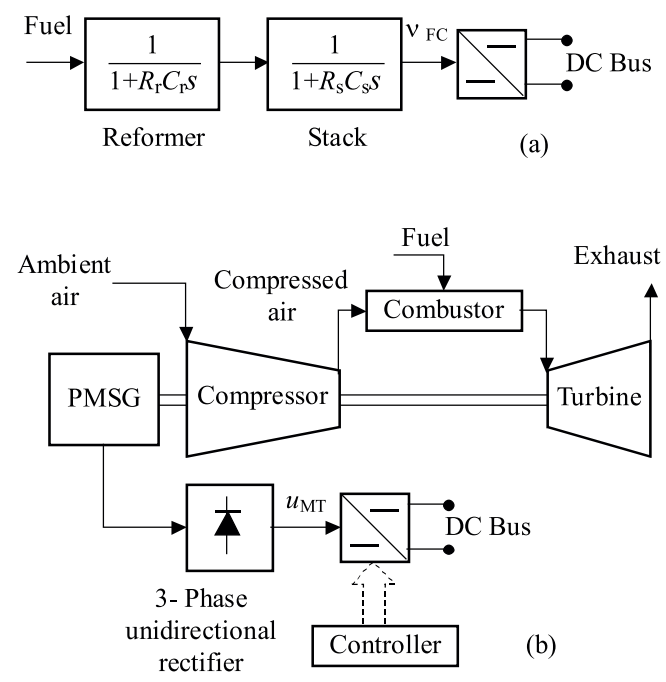

Fig. 7. (a) Electrical model of fuel cell system; (b) Block diagram of microturbine system

Using equations (6) and (18), we have

$$
C_{d c}=\frac{2 \zeta_{n}^{2}\left(P_{n 1, \text { rated }} V_{d c, \text { refn } 1}^{2}+P_{n 2, \text { rated }} V_{d c, \text { ref } n 2}^{2}\right)}{\omega_{l p} \delta_{n}\left(1-\delta_{n}\right) V_{d c, r e f n 1}^{2} V_{d c, r e f n 2}^{2}} .
$$

) It is clear that if $V_{d c, r e f n 1}=V_{d c, r e f n 2}=V_{d c, r e f n}$ and $P_{n 1, \text { rated }}=P_{n 2, \text { rated }}=P_{n, \text { rated }}$, then the total required DC bus capacitor can be determined by the following equation

$$
C_{d c}=\frac{4 \zeta_{n}^{2} P_{n, \text { rated }}}{\omega_{l p} \delta_{n}\left(1-\delta_{n}\right) V_{d c, \text { refn }}^{2}} .
$$

Figure 3(b) shows the steady state droop characteristics of network converters. The output current of these converters can be controlled by the slope of the voltage droop characteristics.

For suitable operation of network converters, DC bus voltage can be changed within two threshold values, $V_{\text {refnui }}$ and $V_{\text {refnli }}$. By the proposed control strategy for network converters, the DC bus voltage must be kept stable within an acceptable limit. Moreover, if the DC bus voltage exceeds the threshold value $V_{\text {refdg }}$, the power produced by DG units is cancelled out. In the system, the power difference between the load demands and power generation of DG units is calculated as follows

$$
\begin{aligned}
& P_{n e t}=P_{L 1}+P_{L 2}+P_{L 3}+P_{L 4}-\sum_{n=1}^{2} P_{F C, n}-\sum_{n=1}^{2} P_{M T, n}, \\
& P_{n 1}+P_{n 2}=P_{n e t}
\end{aligned}
$$

where, $P_{L 1}, P_{L 2}, P_{L 3}$ and $P_{L 4}$ are power consumed by sensitive AC load, nonlinear AC load, unbalanced AC load and DC load connected to the DC bus respectively. $P_{F C, n}$ and $P_{M T, n}$ are output powers of $n$-th fuel cell and microturbine units respectively. Equations (4), (12), (13) and (25) can be used to verify the simulation results. It is obvious that the injected power by network converters to the DC bus, $P_{n 2}$ and $P_{n 2}$, can be in the following modes

a) If $P_{n e t}<0$, then the power generation by DG units has been increased or the power consumed by loads has been reduced. In this case, the additional power available in the DC bus could be injected to the AC grid via network converter.

b) If $P_{n e t}>0$, then the power generation by DG units has been reduced or the power consumed by loads has been increased. In this case the $\mathrm{AC}$ power has been injected to the network converter by the AC grid, in order to supply the DC bus.

c) If $P_{n e t}=0$, then the power generation from DG units is absorbed by the all loads connected to the DC bus. In this case, the AC power injected to the DC bus via network converters is zero.

\section{CONTROL STRATEGIES OF CONVERTERS}

The objective of the converters, connected to the DC bus is to enhance the power quality, reliability and energy efficiency of the system. In this paper, suitable control strategies for each converter are presented. These strategies are mainly based on the control of the DC bus voltage within acceptable limit.

\subsection{Circuit configuration and control scheme of network converters}

The equivalent circuit of network converter is shown in Fig. 4. The converter is represented with three ideal current sources $i_{f a}^{r e f}, i_{f b}^{r e f}$ and $i_{f c}^{r e f}$. The converter manages the amount of current injected to the DC bus and vice versa. As it can be seen in Fig. 4, the input signals of network converter controller are the source phase voltages, $v_{s a}, v_{s b}$ and $v_{s c}$, the source line currents, $i_{s a}, i_{s b}$ and $i_{s c}$, the three phase output currents for this converter $i_{f a}$, $i_{f b}$ and $i_{f c}$, DC bus voltage $v_{d c}$ and reference DC voltage, $V_{d c r e f n} . L_{f}$ is the inductance of the converter filter. $R_{s}$, and $L_{s}$ are the resistance and inductance of the AC grid. This controller uses the hysteresis current control (HCC) switching technique to reduce the high switching 

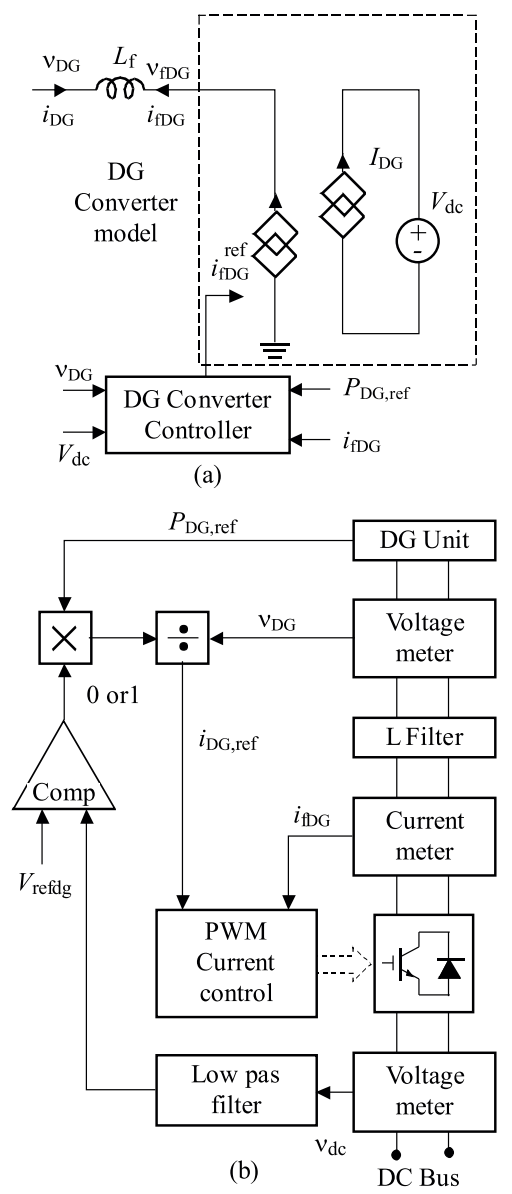

Fig. 8. (a) Equivalent circuit of DG converter; (b) Block diagram of DG converter controller

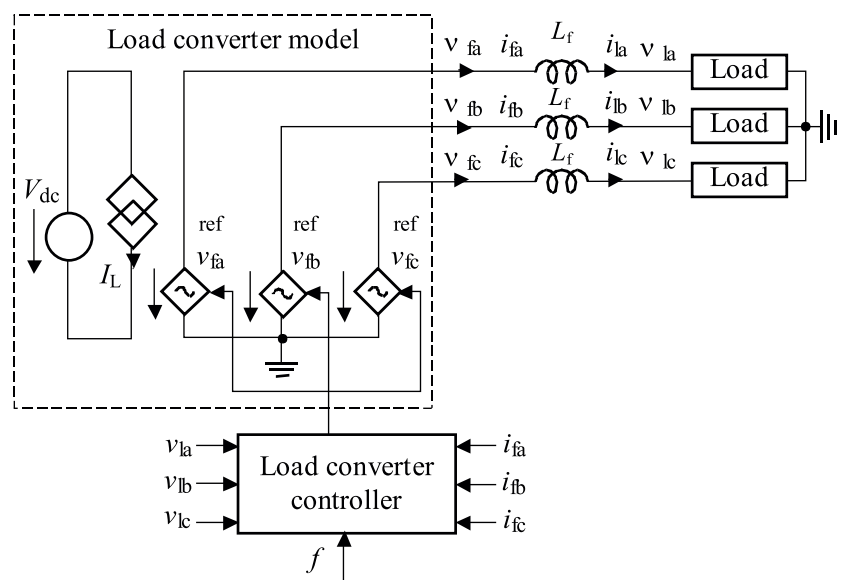

Fig. 9. Equivalent circuit of load converter

frequency harmonic current in the DC bus voltage [6]. From Fig. 4, we have

$$
\left[\begin{array}{l}
i_{s a} \\
i_{s b} \\
i_{s c}
\end{array}\right]=-\left[\begin{array}{l}
i_{f a} \\
i_{f b} \\
i_{f c}
\end{array}\right] .
$$

The circuit configuration and control scheme for each converter has been depicted in Fig. 5. The main part of this scheme is DC voltage regulator. In this paper, the droop control strategy has been used for the network converter, since it does not require any communication system. More details of the DC voltage regulator are shown in Fig. 6. It is obvious that the DC voltage error can be fed to the droop controller, whose droop is $K_{n}$, in order to obtain the injected current $\left(i e, i_{n}\right)$ to the DC bus. The multiplication of $v_{d c}$ and $i_{n}$ determines the injected power to the DC bus of network converter (ie, $\left.P_{n}\right)$. If the DC bus voltage remains between references value, $V_{r e f n l}$ and $V_{r e f n u}$, the signal $P_{n}$ is equal to zero, and the network converter does not exchange power with the external AC system. Also, the power required from the loads is entirely supplied by DG units. If the voltage exceeds the higher reference value, $V_{\text {refnu }}$, the signal $P_{n}$ is negative and the network converter supplies power to the external AC system and if it is below the lower reference value, $V_{\text {refnl }}$, the signal $P_{n}$ is positive and it absorbs power from the external AC system. For the regulator shown in Fig. 6, we have

$$
\begin{aligned}
& I_{n}=K_{n}\left(V_{d c, r e f n}-v_{d c, l p}\right), \\
& P_{n}=v_{d c} i_{n} .
\end{aligned}
$$

Using equations (24) and (25), we obtain

$$
P_{n}=K_{n} v_{d c}\left(V_{d c, r e f n}-v_{d c, l p}\right) .
$$

Equations (24), (25) and (26) in steady state condition can be rewritten as follows

$$
\begin{aligned}
& I_{n}=K_{n}\left(V_{d c, \text { refn }}-V_{d c}\right), \\
& P_{n}=I_{n} V_{d c}=K_{n} V_{d c}\left(V_{d c, \text { refn }}-V_{d c}\right) .
\end{aligned}
$$

Considering the equations (12) and (29), the steady state droop is equal to

$$
R_{n}=\frac{1}{K_{n}}
$$

From $\alpha-\beta-0$ transformation and the power calculation box in Fig. 5, we get

$$
\begin{aligned}
{\left[\begin{array}{c}
v_{s 0} \\
v_{s \alpha} \\
v_{s \beta}
\end{array}\right] } & =T_{\alpha \beta 0}\left[\begin{array}{l}
v_{s a} \\
v_{s b} \\
v_{s c}
\end{array}\right], T_{\alpha \beta 0}=\sqrt{\frac{2}{3}}\left[\begin{array}{ccc}
\frac{1}{\sqrt{2}} & \frac{1}{\sqrt{2}} & \frac{1}{\sqrt{2}} \\
1 & -\frac{1}{2} & -\frac{1}{2} \\
0 & \frac{\sqrt{3}}{2} & -\frac{\sqrt{3}}{2}
\end{array}\right] \\
{\left[\begin{array}{c}
i_{s 0} \\
i_{s \alpha} \\
i_{s \beta}
\end{array}\right] } & =T_{\alpha \beta 0}\left[\begin{array}{c}
v_{i a} \\
i_{s b} \\
i_{s c}
\end{array}\right] \\
Q_{n} & =-v_{s \beta} i_{s \alpha}+v_{s \alpha} i_{s \beta} .
\end{aligned}
$$

The reference active power, $P_{n}$, can be produced by the DC voltage regulator (equation (26)). In addition, the reference reactive power, $Q_{n}$, can be produced by the power calculation box (equation (33)). In this paper, the stationary transformation (Clarke transformation) has been used in order to provide simple and fast control strategy. Thus, the $\alpha-\beta$ component related to 


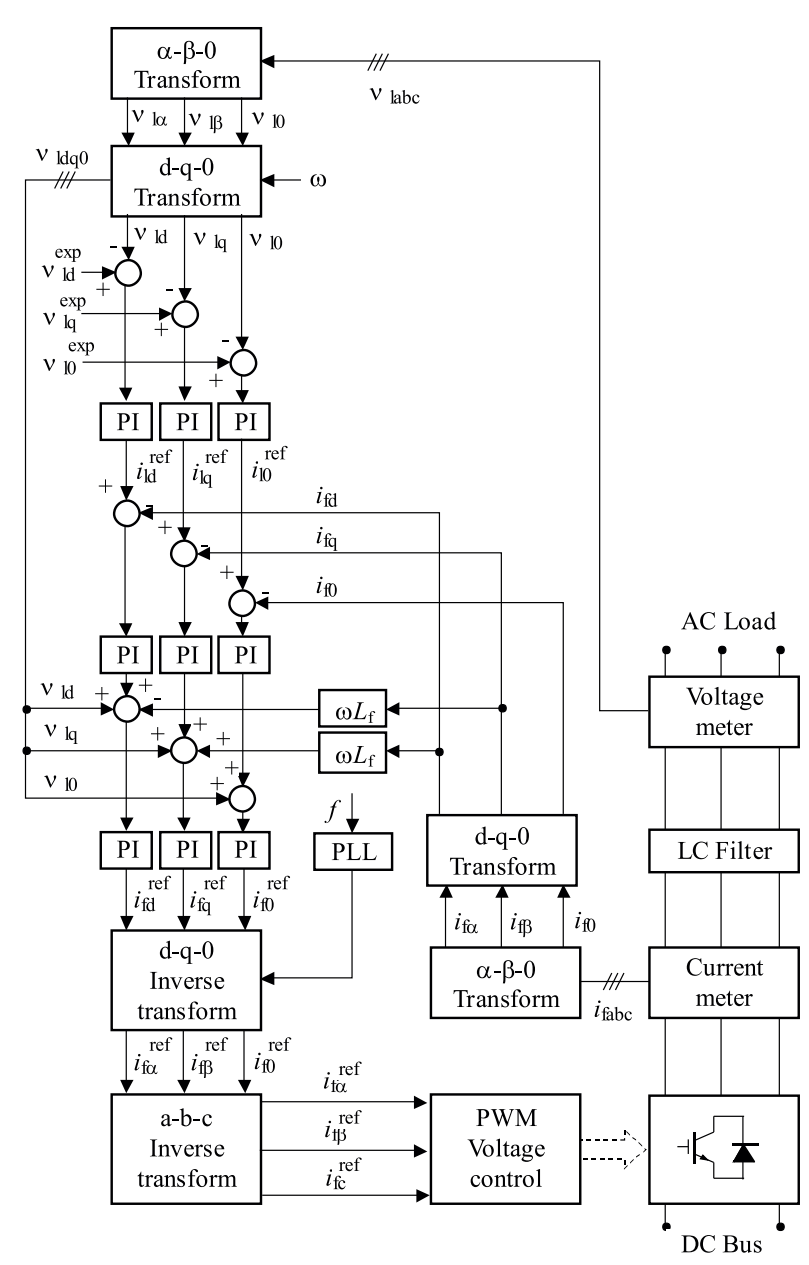

Fig. 10. Control scheme for AC loads connected to the DC bus

the reference current of each network converter can be expressed by equation (34).

$$
\left[\begin{array}{l}
i_{s \alpha}^{r e f} \\
i_{s \beta}^{r e f}
\end{array}\right]=\frac{1}{v_{s \alpha}^{2}+v_{s \beta}^{2}}\left[\begin{array}{cc}
v_{s \alpha} & -v_{s \beta} \\
v_{s \beta} & v_{s \alpha}
\end{array}\right]\left[\begin{array}{c}
P_{n} \\
Q_{n}
\end{array}\right] .
$$

The zero-sequence current in the zero coordinate frame of reference is $i_{0}$, and it is clear that

$$
i_{s 0}^{r e f}=i_{s 0} \text {. }
$$

Finally, the $\alpha-\beta-0$ inverse transformation box shown in Fig. 5 calculates the three-phase current references to be fed into the hysteresis current control scheme. Thus

$$
\begin{aligned}
& {\left[\begin{array}{l}
i_{s a}^{r e f} \\
i_{s b}^{r e f} \\
i_{s c}^{r e f}
\end{array}\right]=T_{a b c}\left[\begin{array}{l}
i_{s 0}^{r e f} \\
i_{s \alpha}^{r e f} \\
i_{s \beta}^{r e f}
\end{array}\right], T_{a b c}=\sqrt{\frac{2}{3}}\left[\begin{array}{ccc}
\frac{1}{\sqrt{2}} & 1 & 0 \\
\frac{1}{\sqrt{2}} & -\frac{1}{2} & \frac{\sqrt{3}}{2} \\
\frac{1}{\sqrt{2}} & -\frac{1}{2} & -\frac{\sqrt{3}}{2}
\end{array}\right],} \\
& {\left[\begin{array}{l}
i_{f a}^{r e f} \\
i_{f b}^{r e f} \\
i_{f c}^{r e f}
\end{array}\right]=-\left[\begin{array}{l}
i_{s 0}^{r e f} \\
i_{s \alpha}^{r e f} \\
i_{s \beta}^{r e f}
\end{array}\right] .}
\end{aligned}
$$

The comparison of the calculated reference currents and the actual currents generated by the network converter will result in the error signal, which controls the switches of the converter.

\subsection{Circuit configuration and control scheme of distributed generation units}

Figure 7(a) shows the dynamic model of each fuel cell unit [24]. Figure 7(b) shows the block diagram of each microturbine (MT) generation unit. MT generation unit has a common rotating shaft, associated with the Permanent Magnet Synchronous Generator (PMSG), combustor, compressor, and turbine. PMSG is also connected to the DC bus via three phase unidirectional rectifier as well as DC-to-DC converter [27].

As shown in Fig. 1, DG converters are connected between the DC bus and the DG units. The equivalent circuit of a DG converter is shown in Fig. 8(a). This converter is represented with an ideal current sources, $i_{f D G}^{r e f}$. The converter manages the amount of current injected to the DC bus. As it can be seen in Fig. 8(a), the input signals of DG converter controller are the DG units output voltage, $v_{D G}\left(v_{F C}\right.$ and $\left.v_{M T}\right)$, the DC bus voltage, $v_{d c}$, the output current for this converter $i_{f D G}$ and the reference active power of each DG unit, $P_{D G}$,ref . It must be noted that the reference active power, $P_{D G}$,ref , is limited considering the DG energy capacity. The control strategy for each DG converter ( $i e$, DC-to-DC converters in figures 8 and 9) has been shown in Fig. 8(b). In this control scheme, the reference active power, $P_{D G, \text { ref }}$ is specified by the related active power management strategy. The reference current, $i_{f D G}^{r e f}$, can be determined as follows

$$
i_{f D G}^{r e f}=\frac{P_{D G, r e f}}{v_{D G}} .
$$

The comparison of the calculated reference currents $i_{f D G}^{r e f}$, and the actual currents generated by the DG converter $i_{f D G}$ will result in the error signal, which is fed to the HCC system, which determines the switching pattern of DC-to-DC converters.

\subsection{Circuit configuration and control scheme of AC loads connected to the DC bus}

As shown in Fig. 1, three load converters are connected between the DC bus and the AC loads. The load converter is VSC with neutral clamped DC capacitors. This topology is characterized by the connection of the neutral point of the load to the midpoint of the clamped DC capacitors. The equivalent circuit of load converter is shown in Fig. 9. This converter is represented with three voltage sources, $v_{f a}^{r e f}, v_{f b}^{r e f}$ and $v_{f c}^{r e f}$. The equations describing load converter voltages and currents are expressed by the following equation

$$
\left[\begin{array}{l}
v_{f a} \\
v_{f b} \\
v_{f c}
\end{array}\right]=\left[\begin{array}{l}
v_{l a} \\
v_{l b} \\
v_{l c}
\end{array}\right]+\left[\begin{array}{ccc}
L_{f} & 0 & 0 \\
0 & L_{f} & 0 \\
0 & 0 & L_{f}
\end{array}\right] \frac{\mathrm{d}}{\mathrm{d} t}\left[\begin{array}{l}
i_{f a} \\
i_{f b} \\
i_{f c}
\end{array}\right]
$$




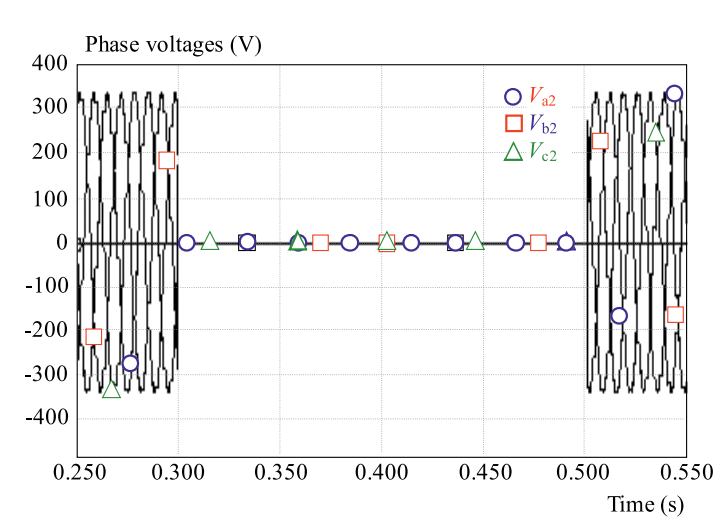

Fig. 11. Phase voltages in AC side of network converter No. 2
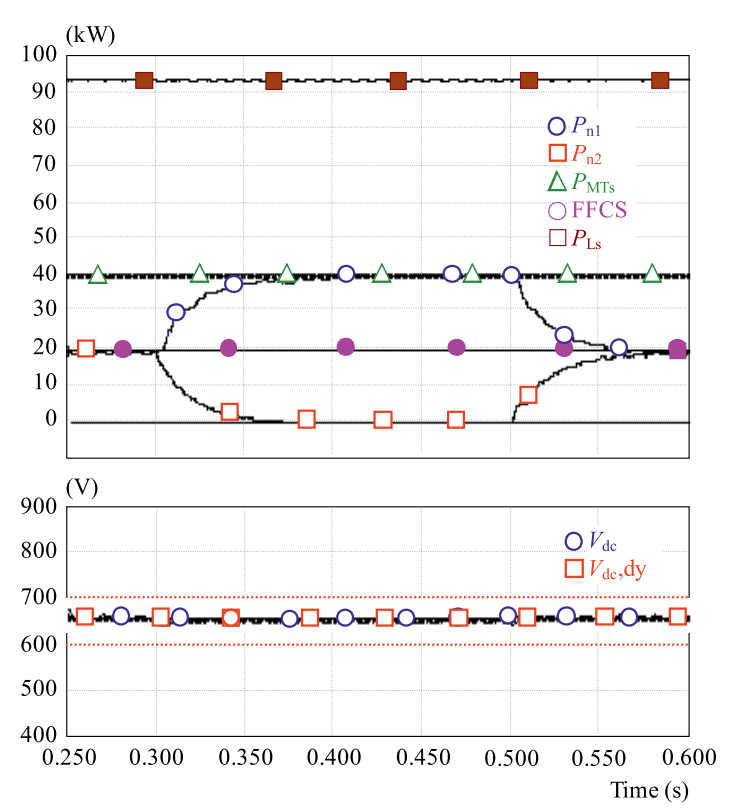

Fig. 12. (up) Active power variations; (down) DC bus voltage

where, $v_{f a}, v_{f b}$ and $v_{f c}$ are the line to neutral three phase output voltages of the load converter. $i_{f a}, i_{f b}$ and $i_{f c}$ are three phase output currents. $v_{l a}, v_{l b}$ and $v_{l c}$ are line to neutral three phase voltages of AC loads. The voltage equations in the $d-q-0$ reference frame are as follows

$$
\begin{gathered}
{\left[\begin{array}{l}
v_{f d} \\
v_{f q} \\
v_{f 0}
\end{array}\right]=\left[\begin{array}{l}
v_{l d} \\
v_{l q} \\
v_{l 0}
\end{array}\right]+\left[\begin{array}{ccc}
L_{f} & 0 & 0 \\
0 & L_{f} & 0 \\
0 & 0 & L_{f}
\end{array}\right] \frac{\mathrm{d}}{\mathrm{d} t}\left[\begin{array}{c}
i_{f d} \\
i_{f q} \\
i_{f 0}
\end{array}\right]} \\
+\left[\begin{array}{ccc}
0 & -\omega L_{f} & 0 \\
\omega L_{f} & 0 & 0 \\
0 & 0 & 0
\end{array}\right]
\end{gathered}
$$

The circuit configuration and control scheme for each converter has been depicted in Fig. 10. The DC-to-AC load converter between the DC bus and AC loads can be controlled by $V-f$ control strategy, which regulates the voltage and the frequency of AC loads. These converters have no loop to regulate the DC bus voltage. In the $V-f$ controller, it is clear that

a) Frequency $(\omega)$ can be obtained by Phase Lock Loop (PLL) using desirable frequency $(e g, 50 \mathrm{~Hz})$. (b) The load phase voltages $\left(v_{l a}, v_{l b}\right.$ and $\left.v_{l c}\right)$ can be detected and transformed to the stationary reference frame with Clarke transformations and then into $d-q-0$ synchronously rotating reference frame using following equations

$$
\begin{aligned}
{\left[\begin{array}{l}
v_{l \alpha} \\
v_{l \beta} \\
v_{l 0}
\end{array}\right] } & =T_{\alpha \beta 0}\left[\begin{array}{l}
v_{l a} \\
v_{l b} \\
v_{l c}
\end{array}\right], \\
{\left[\begin{array}{l}
v_{l d} \\
v_{l q} \\
v_{l 0}
\end{array}\right] } & =T_{d q 0}\left[\begin{array}{l}
v_{l \alpha} \\
v_{l \beta} \\
v_{l 0}
\end{array}\right], \\
T_{d q 0} & =T_{d q 0}^{-1}\left[\begin{array}{ccc}
\cos (\omega t) & \sin (\omega t) & 0 \\
\sin (\omega t) & -\cos (\omega t) & 0 \\
0 & 0 & 1
\end{array}\right] .
\end{aligned}
$$

The load phase voltage should be kept balanced and sinusoidal with constant amplitude and frequency. Therefore the expected load voltages in the $d$ - $q$ - 0 reference frame should have only the following values

$$
\left[\begin{array}{c}
v_{l d}^{e x p} \\
v_{l q}^{e x p} \\
v_{l 0}^{e x p}
\end{array}\right]=\left[\begin{array}{c}
0 \\
0.4 \sqrt{\frac{2}{3}} \\
0
\end{array}\right]
$$

The reference load current in the $d-q-0$ coordinate are:

$$
\left[\begin{array}{c}
i_{l d}^{r e f} \\
i_{l q} r e f \\
i_{l 0} r e f
\end{array}\right]=\left[\begin{array}{c}
\mathrm{PI}\left(v_{l d}-v_{l d}^{e x p}\right) \\
\mathrm{PI}\left(v_{l q}-v_{l q} \exp \right) \\
\mathrm{PI}\left(v_{l 0}-v_{l 0} \exp \right)
\end{array}\right]
$$

The output signals from PI controller can be expressed by the equation (45).

$$
\left[\begin{array}{c}
v_{f d}^{r e f} \\
v_{f q}^{r e f} \\
v_{f 0}^{r e f}
\end{array}\right]=\left[\begin{array}{c}
v_{l d} \\
v_{l q} \\
v_{l 0}
\end{array}\right]+\left[\begin{array}{l}
\mathrm{PI}\left(i_{l d}^{r e f}-i_{f d}\right) \\
\mathrm{PI}\left(i_{l q}^{r e f}-i_{f q}\right) \\
\mathrm{PI}\left(i_{l 0}^{r e f}-i_{f 0}\right)
\end{array}\right]+\left[\begin{array}{c}
-\omega L_{f} i_{f q} \\
\omega L_{f} i_{f d} \\
0
\end{array}\right] .
$$

The reference output voltages for the load converter are transformed to the $a-b-c$ coordinate by using inverse synchronously rotating and stationary reference frames.

$$
\begin{aligned}
& {\left[\begin{array}{c}
v_{f \alpha}^{r e f} \\
v_{f \beta}^{r e f} \\
v_{f 0}^{r e f}
\end{array}\right]=T_{d q 0}^{-1}\left[\begin{array}{c}
v_{f d}^{r e f} \\
v_{f q}^{r e f} \\
v_{f 0}^{r e f}
\end{array}\right],} \\
& {\left[\begin{array}{c}
v_{f a}^{r e f} \\
v_{f b}^{r e f} \\
v_{f c}^{r e f}
\end{array}\right]=T_{a b c}\left[\begin{array}{c}
v_{f \alpha}^{r e f} \\
v_{f \beta}^{r e f} \\
v_{f 0}^{\text {ref }}
\end{array}\right] .}
\end{aligned}
$$

Then the available voltages in the $a-b-c$ coordinate are compared with the triangular wave provided by PWM voltage control box. Therefore the output provides suitable switching pattern of each DC-to-AC converter. 

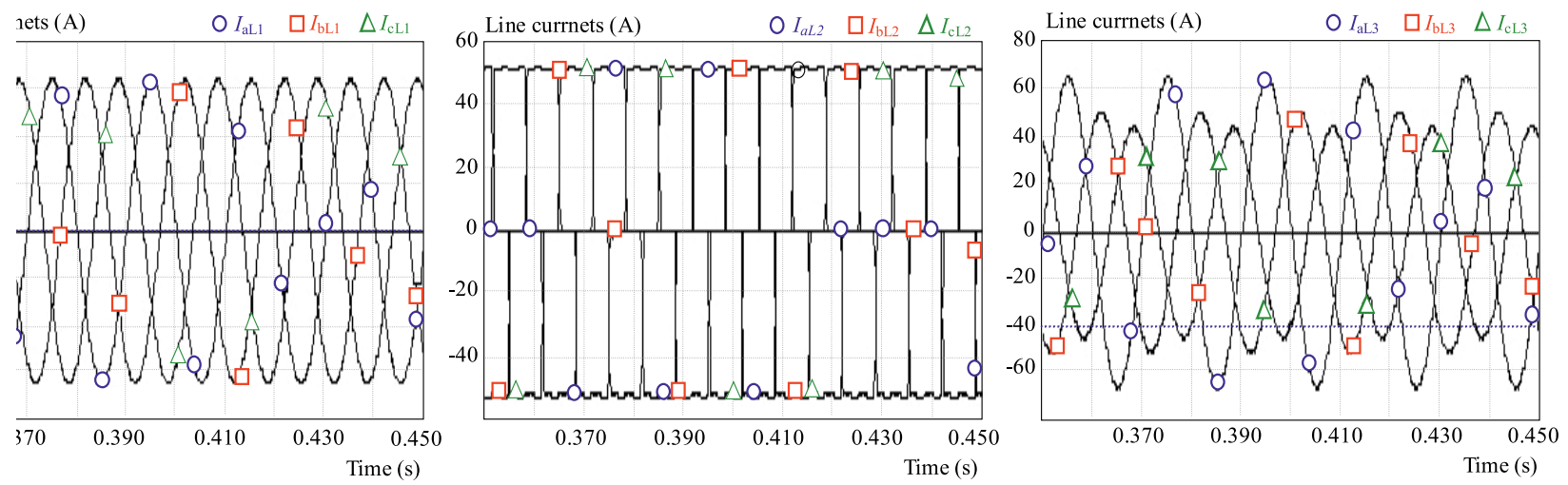

Fig. 13. Line currents at AC loads (L1, L2 and L3) terminals
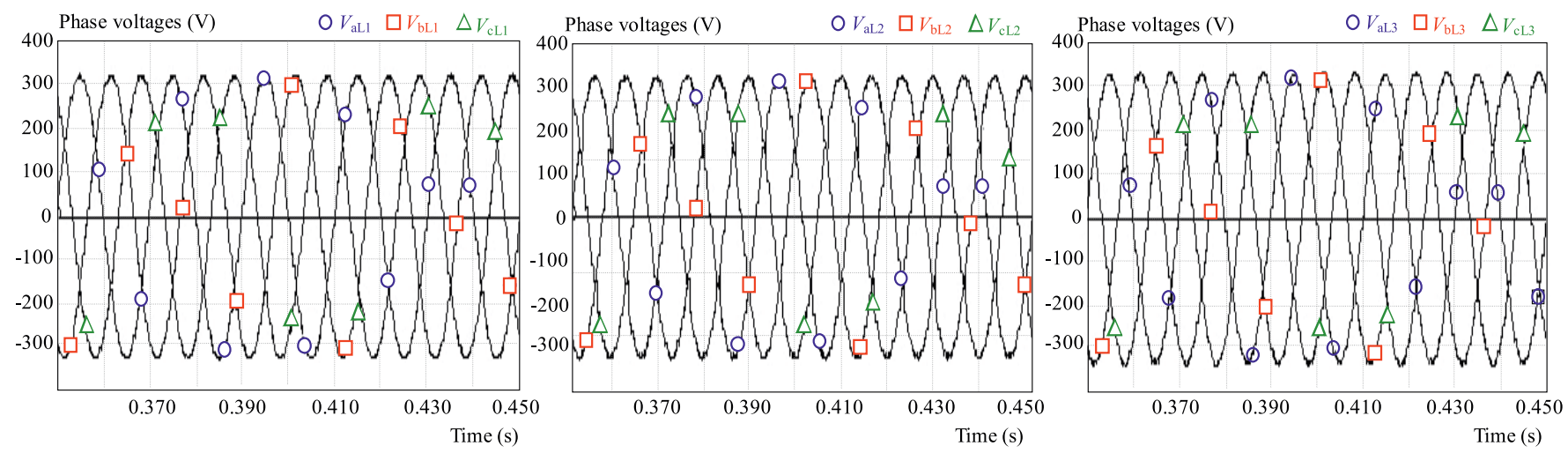

Fig. 14. Grid-side phase voltages of the load converters No. 1 (L1), No. 2 (L2) and No. 3 (L3)
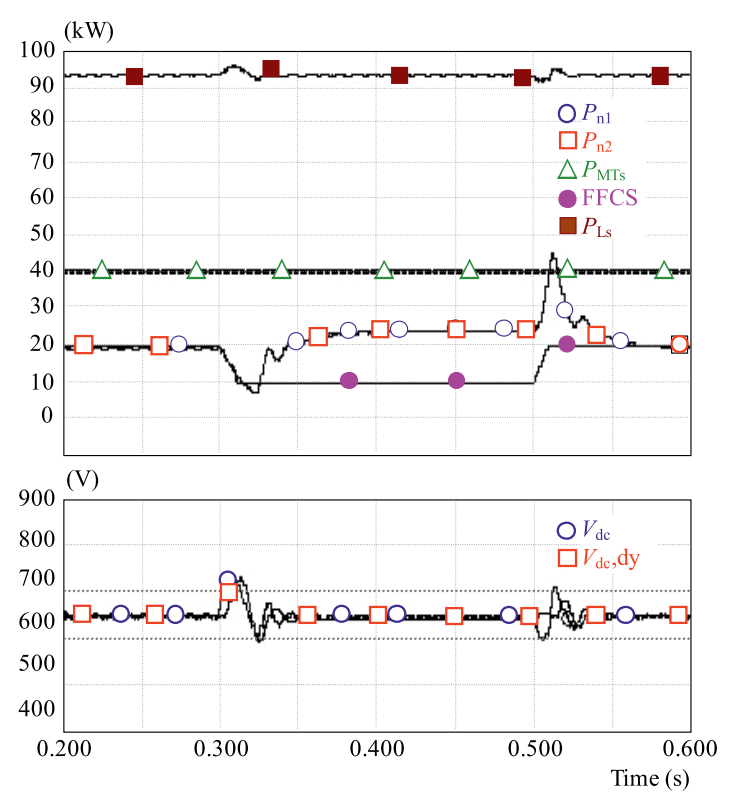

Fig. 15. (up) Active power variation; (down) DC bus voltage

\section{SIMULATION RESULTS}

The system shown in Fig. 1 has been simulated in PSCAD/EMTDC software. It is assumed that two $50 \mathrm{Kw}$ AC-to-DC network converters are in service. It is also assumed that the reference DC voltage is equal to $750 \mathrm{~V}$ and the nominal droop is 5 percent. The rated power for each microturbine and fuel cell unit is assumed to be $20 \mathrm{Kw}$ and $10 \mathrm{Kw}$ respectively. Also, it is assumed that the each microturbine and fuel cell unit is generated the rated power in all of the simulation time. It must be noted that the fuel cell is not able to react fast enough to compensate power fluctuations satisfactorily.

\subsection{Voltage interruption in AC distribution system}

A three phase fault at bus F2 in Fig. 1 has been modeled to represent a voltage interruption during the time period of $t=0.3 \mathrm{~s}$ till $t=0.5 \mathrm{~s}$. Figure 11 illustrates the phase voltages $\left(V_{a s 2}, V_{b s 2}\right.$ and $\left.V_{c s 2}\right)$ at this bus. Figure 12 (up) depicts the variations of the active power in external AC grids $\left(P_{n 1}\right.$ and $\left.P_{n 2}\right)$, the power of $\mathrm{AC}$ and DC loads connected to the DC bus (ie, $P_{L s}=P_{L 1}+$ $\left.P_{L 2}+P_{L 3}+P_{L 4}\right)$ and the output power of DG units injected to the DC bus (ie $P_{M T s}$ and $P_{F C s}$ ). As it can be seen, the active power of the No. 2 network converter $\left(P_{n 2}\right)$ decreases during the fault (interruption) interval, however the active power of the No. 1 network converter $\left(P_{n 1}\right)$ increases because it acts as a $\mathrm{DC}$ voltage regulator. It is clear that during normal operation conditions, two network converters provide the same power to the DC bus while during the voltage interruption; the network converter No. 1 only injects the power to the DC bus. Figure 12 also shows that the injected active powers to the DC bus by DG units is constant. The main reason is that the proposed control strategies for DG converters is able 

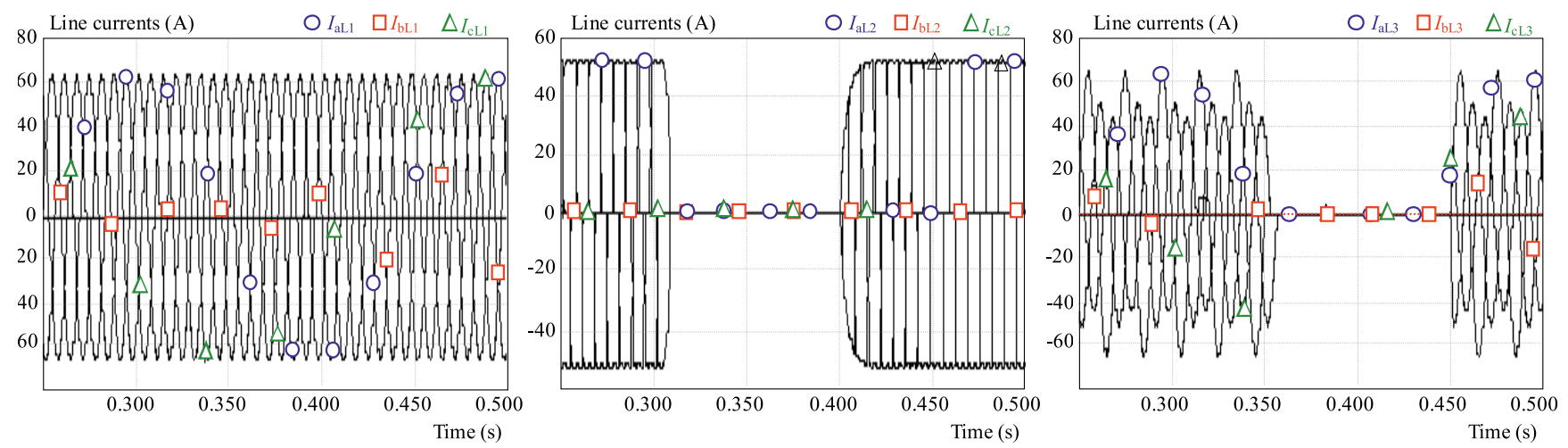

Fig. 16. Line currents at AC loads (L1, L2 and L3) terminals
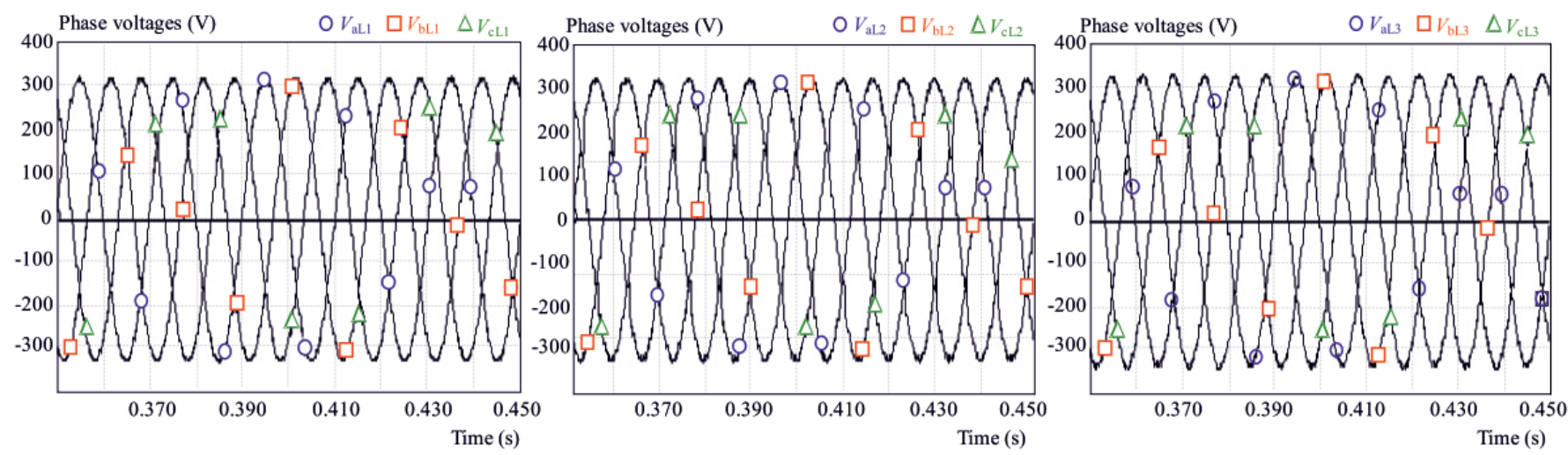

Fig. 17. Grid-side phase voltages of the load converters No. 1 (L1), No. 2 (L2) and No. 3 (L3)
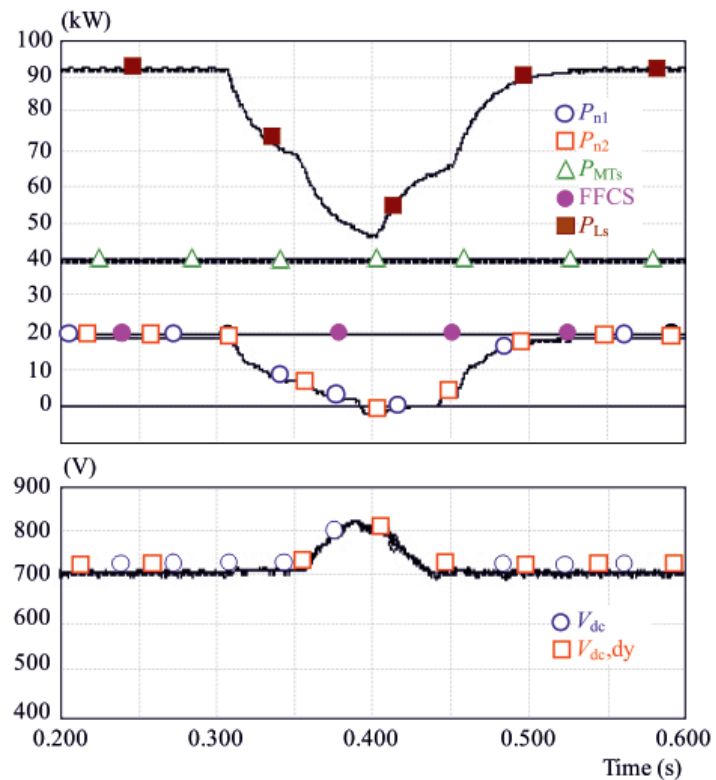

Fig. 18. (up) Active power variation; (down) DC bus voltage

to cancel interactions between DG units and neighbouring loads.

Figure 12 (down) shows the DC bus voltage which remains constant during voltage interruption using the proposed power regulation scheme for network converters. As it can be seen, the actual DC bus voltage $\left(V_{d c}\right)$ follows the DC voltage $\left(V_{d c, d y}\right)$ which is calculated based on the equation (3). Figure 13 shows the line currents of AC loads connected to DC bus. It was found that the load phase currents (L2 and L3) are not sinusoidal. Figure 14 illustrates the phase voltages at the terminal of the sensitive load ( $V_{a L 1}, V_{b L 1}$ and $\left.V_{c L 1}\right)$, the nonlinear load $\left(V_{a L 2}, V_{b L 2}\right.$ and $\left.V_{c L 2}\right)$ and the unbalanced load ( $V_{a L 3}$, $V_{b L 3}$ and $\left.V_{C L 3}\right)$, respectively. It can be seen that high quality voltages have been provided for AC loads. It is clear that the load phase voltage is balanced and sinusoidal with constant amplitude and frequency. To quantify the level of the voltage unbalance, the percentage of unbalance is expressed in accordance with the definition of the "degree of unbalance in three phase system [28]. In this case, the negative sequence unbalance is lower then $1 \%$ which is acceptable with respect to $2 \%$ admitted by international standards.

\subsection{Reference Power for DG units}

In this section, the reference active power of fuel cells has been reduced by $50 \%$ of rated power, and subsequently increased to its rated power. Figure 15 (up) shows the instantaneous active power of external AC grids and DG units and AC and DC loads. It can be said that the suggested control strategy for fuel cell converter provides reasonable response. As shown in Fig. 15, the instantaneous active power of network converters $\left(P_{n 1}\right.$ and $\left.P_{n 2}\right)$ are equal showing the proper load sharing. Figure 15 (down) also depicts the DC bus voltage with a voltage swell. It is also clear that when the reference of the active power has been increased to the rated power, the DC bus voltage faces to the sag phenomena. As it can be seen, 
the actual DC bus voltage $\left(V_{d c}\right)$ follows the DC voltage $\left(V_{d c, d y}\right)$ which is calculated using equation (3).

\subsection{Temporary loss of load converter}

Figures 16 to 18 show the simulation results due to the loss of load converters No. 2 and No. 3 supplying nonlinear (L2) and unbalanced loads (L3), respectively. Figure 16 shows the line currents of AC loads connected to DC bus due to loss of the associated converters for 0.1 second.

Figure 17 illustrates the phase to ground voltages at the terminal of the sensitive load $\left(V_{a L 1}, V_{b L 1}\right.$ and $\left.V_{c L 1}\right)$ and the unbalanced load $\left(V_{a L 3}, V_{b L 3}\right.$ and $\left.V_{c L 3}\right)$, respectively. It can be seen that high quality voltages have been provided for AC loads. It is clear that these voltages are not affected by the loss of the converter. In this case, the negative sequence unbalance is lower then $1 \%$ which is acceptable. It should be noticed that international standards admit unbalance lower than $2 \%$ [28].

Figure 18 (up) shows the instantaneous active power of external AC grids and DG units as well as AC and DC loads. In this situation due to the loss of the load converter, the network converters return the additional power from the DC bus to the external AC system. Figure 18 (down) shows the DC bus voltage which is within acceptable limit. As it can be seen, the actual DC bus voltage $\left(V_{d c}\right)$ follows the DC voltage $\left(V_{d c, d y}\right)$ which is calculated using equation (3). The other simulation results which are not presented in this paper have been verified by equations (10) and (22).

\section{CONCLUSION}

This paper proposes a combined operation of the $\mathrm{AC}$ and DC distribution system with the DG units. The proposed system can compensate voltage sags and swells as well as voltage interruptions under different operating conditions. The PSCAD/EMTDC software has been used for the modeling and the simulation of the system. We made the main concept of the power management strategy, and then, on the power flow and voltage control. The simulation results show that the proposed strategies provide the suitable load sharing between network converters, while the DC bus voltage remains under acceptable level. The results also show that the proposed system can protect the sensitive loads against disturbances. It is shown that the nonlinear load does not inject harmonic currents to the AC grid and unbalancing would not be occurred in the AC grid. The results also show that the proposed system can supply the unbalanced AC load with balanced voltages. It is shown that the unbalancing would not be occurred in the AC and DC network by the unbalanced AC load.

\section{LIST OF ABBREVIATIONS AND SYMBOLS}

DG distributed generations

UPS uninterruptible power supply
VSC voltage source converters

UPF unity power factor

PWM pulse-width modulation

HCC hysteresis current control

PMSG permanent magnet synchronous generator

PLL phase lock loop

$A, b, c \quad$ phase order in $a-b-c$ coordinate

$D, q, 0$ phase order in $d$ - $q$-0 coordinate

$V_{d c, \text { refni }}$ DC reference voltage of the $i$-th network con-

verter

$I_{n i} \quad$ output current of the $i$-th network converter

$P_{n i} \quad$ output DC power of the $i$-th network converter

$R_{n i} \quad$ equivalent resistance of the $i$-th network converter

$I_{M T s} \quad$ output current of the microturbine units

$I_{F C s} \quad$ output current of the fuel cell units

$I_{L 1} \quad$ output current of the load converters No. 1

$I_{L 2} \quad$ output current of the load converters No. 2

$I_{L 3} \quad$ output current of the load converters No. 3

$I_{L 4} \quad$ current taken by load directly connected to DC bus

$I_{c} \quad$ circulating current

$P_{M T, n} \quad$ output power of $n$-th fuel cell and microturbine units

$P_{F C, n} \quad$ output power of $n$-th fuel cell and microturbine units

$P_{n e t} \quad$ total power consumed by all loads connected to the DC bus

$P_{L 1} \quad$ power consumed by L1

$P_{L 2} \quad$ power consumed by L2

$P_{L 3} \quad$ power consumed by L3

$P_{L 4} \quad$ power consumed by L4

$K \quad$ controller gain

$\delta \quad$ voltage droop in general

$P_{n} \quad$ reference active power of each network converter

$Q_{n} \quad$ reference reactive power of each network converter

$i_{f i}^{r e f} \quad$ reference current for each network converter for phase $i$

$P_{D G, \text { ref }}$ reference active power for each DG unit

$I_{f D G}^{r e f} \quad$ reference current for each DG unit

$V_{f i}^{r e f}$ reference current for each load converter for phase $i$

$F \quad$ frequency in general

$v_{i} \quad$ instantaneous line-to-neutral voltage for phase $i$

$i_{i} \quad$ instantaneous phase current for phase $i$

\section{REFERENCES}

[1] JOHnson, B. K.-LASSETER, R.: An Industrial Power Distribution System Featuring UPS Properties, In Proc. 24th Annu. IEEE PESC, 1993, pp. 759-765.

[2] GHOSH, A.-JOshI, A.: The Concept and Operating Principles of a Mini Custom Power Park, IEEE Trans. Power Del. 19 No. 4 (2004.), 1766-1774.

[3] CHOI, S. S.-LI, B. H.-VILAthGamuWA, D. M. : Design and Analysis of the Inverter-Side Filter used in the Dynamic 
Voltage Restorer, IEEE Trans. Power Del. 17 No. 3 (2002), $857-864$.

[4] GHOSH, A.-LEDWICH, G.: Compensation of Distribution System Voltage using DVR, IEEE Trans. Power Del. 17 No. 4 (2002), 1030-1036,.

[5] IYER, S.-GHOSH, A.-JOSHI, A. : Inverter Topologies for DSTATCOM Applications - a Simulation Study, Electric Power Systems Research, 75 No. 2-3, (2005), 161-170.

[6] GHOSH, A.-LEDWICH, G.: Load Compensating DSTATCOM in Weak AC Systems, IEEE Trans. Power Del. 18 No. 4, (2003), 1302-1309.

[7] FUJITA, V.-AKAGI, H.: The Unified Power Quality Conditioner: The Integration of Series- and Shunt-Active Filters, IEEE Trans. Power Electron. 13 No. 2 (1998), 315-322.

[8] GHOSH, A.-LEDWICH, G. A. : Unified Power Quality Conditioner (UPQC) for Simultaneous Voltage and Current Compensation, Elect. Power Syst. Res. 59 No. 1 (2001), 55-63.

[9] DAVIS, M. W.: Distributed Resource Electric Power Systems Offer Significant Advantages over Central Station Generation and T\&D Power Systems, in Proc. Power Engineering Soc. Summer Meeting, vol. 1, 2002, pp. 61-69.

[10] HADJSAID, N.-CANARD, J. F.-DUMAS, F.: Dispersed Generation Increases the Complexity of Controlling, Protecting, and Maintaining the Distribution Systems, IEEE Computer Applications in Power 12 No. 2 (1999), 22-28.

[11] BLAABJERG, F.-CHEN, Z.-KJAER, S. B.: Power Electronics as Efficient Interface in Dispersed Power Generation Systems, IEEE Trans. Power electron. 19 No. 5 (2004).

[12] ARULAMPALAM, A.-BARNES, M.-ENGLER, A.GOODWIN, A.-JENKINS, N.: Control of Power Electronic Interfaces in Distributed Generation Microgrids, International Journal of Electronics 91 No. 9 (Sep 2004), 503-523.

[13] MAREI, M. I.-El-SAADANY, E. F.-SALAMA, M. M. A. : Flexible Distributed Generation (FDG), in Proc. IEEE Power Engineering Soc. Summer Meeting,, vol. 1, 2002, pp. 49-53.

[14] THAND, G. S.-ZHANG, R.-XING, K.-LEE, F. C.-BOROYEVICH, D.: Modeling, Control and Stability Analysis of a PEBB based DC DPS, IEEE Trans. Power Del. 14 No. 2 (1999), 497-505.

[15] GRUZS, T.-HALL, J.-AC: DC or Hybrid Power Solutions for Today's Telecommunications Facilities, In Proc. IEEE INTELEC, 2000, pp. 361-368.

[16] BARAN, M. E.-MAHAJAN, N. R. : DC Distribution for Industrial Systems: Opportunities and Challenges, IEEE Trans. Ind. App. 39 No. 6 (2003), 1596-1601.

[17] PAUL, D. : DC Traction Power System Grounding, IEEE Trans. Ind. App. 38 No. 3 (2002), 818-824.

[18] MAREI, M. I.-El-SAADANY, E. F.-SALAMA, M. M. A. : A Novel Control Algorithm for the DG Interface to Mitigate Power Quality Problems, IEEE Trans. Power Del. 19 No. 3 (2004), 1384-1392.

[19] AGUSTONI, A.-BREnNA, M.-TIRONI, E. : Proposal for a High Quality DC Network with Distributed Generation, CIRED, 17-th International Conference on Electricity Distribution, Barcelona, 2003.

[20] MAHMOODI, M.-GHAREHPETIAN, G. B.-ABEDI, M.NOROOZIAN, R. : Novel and Simple Control Strategy for Fuel Cell Converters in DC Distribution Systems, First International Power and Energy Conference, PECon, Putrajaya, Malaysia, Nov. 2006, pp. 358-362.

[21] MAHMOODI, M.-GHAREHPETIAN, G. B.-ABEDI, M.NOROOZIAN, R. : A Suitable Control Strategy for Source Converters and a Novel Load-Generation Voltage Control Scheme for DC Voltage Determination in DC Distribution Systems, First International Power and Energy Conference PECon, Putrajaya, Malaysia, Nov 2006, pp. 363-367.

[22] CIGRE Technical Brochure on Modeling New Forms of Generation and Storage, November 2000.
[23] KARLSSON, P.-SVENSSON, J. : DC Bus Voltage Control for a Distributed Power System, IEEE Trans. Power Electron. 18 No. 6 (2003), 1405-1412.

[24] KIM, Y.-KIM, S.: An Electrical Modeling and Fuzzy Logic Control of a Fuel Cell Generation System, IEEE Trans. Energy Conv. 14 No. 22 (1999), 239-244.

[25] MARWALI, M. N.-KEYHANI, A.: Control of Distributed Generation Systems Part I: Voltage and Current Control, IEEE Transactions on Power Electronics 19 No. 6, (2004), 1541-1550.

[26] MARWALI, M. N.-JUNG, J. W.-KEYHANI, A. : Control of Distributed Generation Systems Part II: Load Sharing, IEEE Transactions on Power Electronics 19 No. 6 (2004), 1551-1561.

27] Al-HINAI, A.-FELIACHI, A. : Dynamic Model of a Microturbine Used as a Distributed Generator, IEEE Proc. 34-th Southeastern Symposium on System Theory, 2002, pp. 209-213.

[28] SHORT, T.: Electric Power Distribution Handbook, CRC Press, 2004.

Received 11 July 2009

Reza Noroozian was born in Iran. He is an assistant professor with the department of Power Engineering, University of Zanjan, Iran. He received his BSc from Tabriz University, Tabriz, Iran, in 2000. He received his MSc and also PhD degrees in electrical engineering from Amirkabir University of Technology (AUT), Iran, in 2003 and 2008, respectively. His areas of interest include: Power Electronic, Power System, Power Quality, Integration and Control of Renewable Generation Units, Custom Power, Micro-grid Operation, Distributed Generation Modelling, Operation and Interface Control.

Mehrdad Abedi received his $\mathrm{BSc}, \mathrm{MSc}$ and $\mathrm{PhD}$ from Tehran University, London University and Newcastle University in 1970, 1973, and 1977, respectively. He worked for G.E.C. (UK) till 1978. Since then he joined EE Dept of Amirkabir University (Tehran, Iran) where he is now the professor and member of Center of Excellency on Power System. Prof. Abedi has published more than 25 books and 160 papers in journals and conferences. He is distinguished professor in Iran and is prize winner for two outstanding books. He is also member of Iranian Academy of Science and member of CIGRE. His main interest is electrical machines and power systems modeling, operation and control.

Gevorg Gharehpetian was born in Tehran, in 1962. He received his $\mathrm{BS}, \mathrm{MS}$ and $\mathrm{PhD}$ degrees in electrical engineering in 1987, 1989 and 1996 from Tabriz University, Tabriz, Iran and Amirkabir University of Technology (AUT), Tehran, Iran and Tehran University, Tehran, Iran, respectively, graduating all with First Class Honors. He has been holding the Assistant Professor position at AUT from 1997 to 2003, the position of Associate Professor from 2004 to 2007 and has been Professor since 2007. The power engineering group of AUT has been selected as a Center of Excellence on Power Systems in Iran since 2001. He was selected by the ministry of higher education as the distinguished professor of Iran and by IAEEE (Iranian Association of Electrical and Electronics Engineers) as the distinguished researcher of Iran and was awarded the National Prize in 2008 and 2010, respectively. Prof. Gharehpetian is a senior member of IEEE and IAEEE and a member of the central board of IAEEE. Since 2004, he is the Editor-in-Chief of the Journal of IAEEE. He is the author of more than 350 journal and conference papers. His teaching and research interest include power system and transformers transients, FACTS devices, DG and HVDC transmission. 